\title{
Optimum marker selection of acute liver damage in rats in the experiment
}

\author{
K.A. Popov ${ }^{1}$, I.Y. Tsymbalyuk ${ }^{1}$, R.I. Sepiashvili ${ }^{2}$, I.M. Bykov ${ }^{1}$, E.S. Ustinova ${ }^{1}$, M.I. Bykov ${ }^{1}$ \\ ${ }^{1}$ Kuban State Medical University, Krasnodar, Russian Federation \\ ${ }^{2}$ Peoples' Friendship University of Russia (RUDN University), Moscow, Russian Federation
}

\begin{abstract}
Annotation. Relevance. Assessment of liver damage and functional state is one of the leading tasks of clinical and laboratory diagnostics. Traditionally used methods for determining the activity of a number of indicator enzymes in blood with relative organ-specificity, such as aspartate aminotransferase, alanine aminotransferase, lactate dehydrogenase, sorbitol dehydrogenase, alkaline phosphatase, and $\gamma$-glutamyl transferase, have low specificity for liver diseases. In this regard, the determination of the optimal marker of acute liver injury is an urgent problem. Aim. The purpose of the study is to determine the dynamics of changes in liver damage markers in rats at different periods of reperfusion after 20 minutes of ischemia in order to select the indicators that most informatively characterize the state of test-animals under conditions of correction of ischemia-reperfusion syndrome. Materials and methods: the study was performed on 120 white nonlinear male rats weighing 200-250 grams. The animals were divided into 8 groups of 15 test-animals; all of them were simulated liver ischemia by clamping the analog of the hepatoduodenal ligament with a vascular clamp for 20 minutes. Then, blood was taken from different groups of rats at different reperfusion times - 5, 15, 30, 60, 120, 180 minutes, 8 hours and a day. In the blood plasma of laboratory animals, the activity of alanine aminotransferase (ALT), aspartate aminotransferase (AST), lactate dehydrogenase (LDH), glutathione transferase (GST), and lactate concentration were determined. Results: the results obtained allowed us to characterize two main peaks of indicators: a 5-minute period after restoration of blood flow - the maximum activity of glutathione transferase and lactate concentration, increased by 3.9-4.7 times; $60-180$ minutes of reperfusion is the peak of aminotransferase activity, a significant increase in the activity of which begins 60 minutes after the restoration of blood flow and reaches its maximum by the 3rd hour of reperfusion, and LDH, the peak of which is recorded already by the 60th minute of revascularization. At the same time, after 8 hours of reperfusion, an obvious tendency for a decrease in all studied parameters was determined, which ends a day after modeling ischemia with a decrease to the level of control values. Conclusion: the assessment of organ damage in the ischemic period and the anti-ischemic effect of metabolic drugs can be carried out with the determination of an increase in lactate concentration and glutathione transferase activity almost immediately after restoration of blood flow. The development of injuries during the reperfusion period is more expedient to assess by determining AST, ALT and LDH after a 3-hour period of blood flow restoration, at which time the maximum values of markers are recorded under the condition of 20-minute total liver ischemia.
\end{abstract}

Key words: liver, ischemia, reperfusion, cytolysis, hepatocytes

(C) Popov K.A., Tsymbalyuk I.Y., Sepiashvili R.I., Bykov I.M., Ustinova E.S., Bykov M.I., 2020

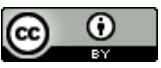

This work is licensed under a Creative Commons Attribution 4.0 International License

https://creativecommons.org/licenses/by/4.0/ 
Author contributions. Popov K.A. - design and performance of experimental procedure; Tsymbalyuk I.Y. - planning and performance of experimental procedure with test animals; Sepiashvili R.I. - results and discussion, article writing; Bykov I.M. concept and design of study, results and discussion; Ustinova E.S. -results and discussion; Bykov M.I. - planning and performance of experimental procedure.

Conflict of interest statement. The authors declare no conflict of interest.

Financing. The study was carried out as part of the state assignment of the Ministry of Health of the Russian Federation № AAAA-A18-118122690052-3.

Received 29.08.2020. 2020. Accepted 11.09.2020.

For citation: Popov K.A., Tsymbalyuk I.Y., Sepiashvili R.I., Bykov I.M., Ustinova E.S., Bykov M.I. Optimum marker selection of acute liver damage in rats in the experiment. RUDN Journal of Medicine. 2020;24(4):293-303. DOI: 10.22363/23130245-2020-24-4-293-303

\title{
Выбор оптимального маркера острого повреждения печени крыс в эксперименте
}

\author{
К.А. Попов ${ }^{1}$, И.Ю. Цымбалюк ${ }^{1}$ Р.И. Сепиашвили ${ }^{2}$, И.М. Быков ${ }^{1}$, \\ Е.С. Устинова ${ }^{1}$, М.И. Быков ${ }^{1}$ \\ ${ }^{1}$ Кубанский государственный медицинский университет, Краснодар, Российская Федерация \\ ${ }^{2}$ Российский университет дружбы народов, Москва, Российская Федерация
}

Аннотация. Актуальность. Оценка повреждения и функционального состояния печени является одной из ведущих задач клинико-лабораторной диагностики. Традиционно используемые методы определения в крови активности ряда индикаторных ферментов, обладающих относительной органоспецифичностью, таких как аспартатаминотрансфераза, аланинаминотрансфераза, лактатдегидрогеназа, сорбитолдегидрогеназа, щелочная фосфатаза и ү-глутамилтрансфераза обладают низкой их специфичностью по отношению к заболеваниям печени. В связи с этим определение оптимального маркера острого повреждения печени является актуальной проблемой. Цель: определение динамики изменений маркеров повреждения печени у крыс на разных сроках реперфузии после 20-ти минутной ишемии для выбора показателей, наиболее информативно характеризующих состояние животных в условиях проведения коррекции ишемически-реперфузионного синдрома. Материалы и методы: исследование проведено на 120 белых нелинейных крысах-самцах массой 200-250 грамм. Животные были разделены на 8 групп по 15 особей, всем животным выполнялось моделирование ишемии печени путем пережатия аналога печеночно-двенадцатиперстной связки сосудистым зажимом на 20 минут. Затем у разных групп крыс производили забор крови в разные сроки реперфузии - 5, 15, 30, 60, 120, 180 минут, 8 часов и сутки. В плазме крови лабораторных животных определяли активность аланинаминотрансферазы (АЛТ), аспартатаминотрансферазы (АСТ), лактатдегидрогеназы (ЛДГ), глутатионтрансферазы (ГST) и концентрацию лактата. Результаты: полученные результаты позволили охарактеризовать два основных пика показателей: 5-минутный период после восстановления кровотока - максимум активности глутатионтрансферазы и концентрации лактата, увеличенных в 3,9-4,7 раза; 60-180 минут реперфузии - пик активности аминотрансфераз, значительный рост активности которых начинается с 60-ти минут после восстановления кровотока и достигает максимума к 3-му часу реперфузии, и ЛДГ, пик активности которой регистрируется уже к 60-й минуте реваскуляризации. При этом через 8 часов реперфузии определена очевидная тенденция снижения всех изученных показателей, которая заканчивается спустя сутки после моделирова- 
ния ишемии снижением до уровня контрольных значений. Заключение: оценка повреждения органа в ишемическом периоде и противоишемического действия метаболических препаратов может проводиться с определением нарастания концентрации лактата и активности глутатионтрансферазы практически сразу после восстановления кровотока. Развитие повреждений в реперфузионный период более целесообразно оценивать путем определения АСТ, АЛТ и ЛДГ после 3-часового периода восстановления кровотока, в это время регистрируются максимальные значения маркеров при условии 20-минутной тотальной ишемии печени.

Ключевые слова: печень, ишемия, реперфузия, цитолиз, гепатоциты

Вклад авторов: Попов К.А. - дизайн и выполнение лабораторной части исследования; Цымбалюк И.Ю. - непосредственное планирование и выполнение экспериментальной работы с лабораторными животными; Сепиашвили Р.И. обсуждение результатов исследования, написание текста статьи; Быков И.М. - концепция и дизайн исследования, обсуждение результатов; Устинова Е.С. - обсуждение результатов, оформление введения и формулировка заключения; Быков М.И. - планирование и выполнение экспериментальной части исследования.

Заявление о конфликте интересов. Авторы заявили об отсутствии конфликта интересов.

Информация о финансировании. Исследование выполнено в рамках государственного задания Министерства здравоохранения Российской Федерации № AААА-А18-118122690052-3.

Поступила 29.08.2020. Принята 11.09.2020.

Для цитирования: Попов К.А., Цымбалюк И.Ю., Сепиашвили Р.И., Быков И.М., Устинова Е.С., Быков М.И. Выбор оптимального маркера острого повреждения печени крыс в эксперименте // Вестник Российского университета дружбы народов. Серия: Медицина. 2020. T. 24. № 4. C. 293-303. DOI: 293-303. DOI: 10.22363/2313-0245-2020-24-4-293-303

In medical practice, the assessment of liver damage and functional state is one of the leading tasks of clinical and laboratory diagnostics. For this purpose, the determination of the activity of a number of indicator enzymes in the blood with relative organ-specificity is traditionally used, such as aspartate aminotransferase (AST), alanine aminotransferase (ALT), lactate dehydrogenase (LDH), alkaline phosphatase and $\gamma$-glutamyltransferase [1]. A change in the activity of aminotransferases often indicates cytolysis of liver cells, the activity of alkaline phosphatase increases with cholestasis [2, 3]. Taking into account the proteinsynthesizing function of the liver, in some cases it can be informative to determine the content of serum albumin in the blood plasma, especially in chronic diseases, and the prothrombin time, which reflects the activity of blood coagulation factors, also synthesized in the liver. Against the background of the detoxification function, the determination of bilirubin and its metabolites may be informative [4]. The main disadvantage of all the listed markers is their low specificity in relation to liver diseases. Meanwhile, by verification of liver damage by other methods, the assessment of the above indicators is justified for laboratory monitoring purposes $[5,6]$. There are dynamic methods for assessing the functional state of the liver, based on determining the rate of metabolism in the liver of various substrates, such as bromsulphthalein, indocyanine green, lidocaine, etc. [7-9]. These methods are rarely used in clinical practice, since they are invasive, require complex equipment and a long study time. The principles and approaches to the assessment of experimental liver damage in rats are similar; however, there are features associated with the severity and diagnostic significance of certain markers, as well as with the dynamics of changes in the process of damage [10, 11].

The purpose of the present study was to determine the dynamics of changes in liver damage markers in rats at different periods of reperfusion after 20 minutes of ischemia in order to select the indicators that characterize the state of animals under conditions of correction of ischemia-reperfusion syndrome most informatively. 


\section{Material and methods}

The study was carried out on 120 laboratory animals, white non-linear male rats (weighing 200250 grams). The animals were divided into 8 groups of 15 test-animals; all animals were simulated liver ischemia by clamping the analog of the hepatoduodenal ligament with a vascular clamp for 20 minutes. Then, blood was taken from different groups of rats at different reperfusion times $-5,15,30,60,120,180$ minutes, 8 hours and a day. Experimental work with laboratory animals was performed under general anesthesia using Zoletil 100 (Virbac, France) at a dosage of 10 $\mathrm{mg} / \mathrm{kg}$ intramuscularly. The study was approved by the independent ethics committee at the FSBEI HE «KubSMU» of the Ministry of Health Care of Russia (Protocol No. 51 of May 23 ${ }^{\text {rd }}$, 2017) and was carried out in accordance with the principles set out in the «European Convention for the Protection of Vertebrate Animals» (Strasbourg, 1986). Comparison of the data obtained in the experiment in the rats of the experimental groups was also carried out with the results of evaluating similar indicators in the group of intact animals (control group, $\mathrm{n}=20$ ) kept in similar conditions [2].

In the blood plasma of laboratory animals, the activity of alanine aminotransferase (ALT), aspartate aminotransferase (AST), lactate dehydrogenase (LDH), and lactate concentration were determined by kinetic methods using the Vital Development Corporation reagent kits (St. Petersburg, Russia). The activity of glutathione transferase (GST) was determined according to a method involving the registration of changes in optical density at $340 \mathrm{~nm}$ as a result of condensation of glutathione with dinitrochlorobenzene [12].

The data obtained were statistically processed by means of the AnalystSoft Inc. software and the statistical analysis program StatPlus, Version 7 (link: www.analystsoft.com/ru/). Taking into account the small sample size and abnormal distribution (assessed by the Shapiro-Wilk test), the nonparametric KruskalWallis test (for several independent groups) was used to determine the significance of differences between the parameters of the groups of animals with different reperfusion times, as well as the control group with the subsequent (if necessary) pairwise comparison by means of the Mann-Whitney test. The results are presented in the article as a median, error bars reflect the spread between the $25^{\text {th }}$ and $75^{\text {th }}$ percentiles. Differences between the group indicators were considered statistically significant at $\mathrm{p}<0.05$.

\section{Results and discussion}

Analysis of changes in classical markers in the dynamics of the development of ischemia-reperfusion damage in rats showed different results for the activity of ALT, AST, LDH, GST and lactate concentration. The activity of all markers increased already at the $5^{\text {th }}$ minute of reperfusion, but later on, the dynamics of indicators was different. ALT activity (Table 1) increased by the $5^{\text {th }}$ minute of the reperfusion period by 2.1 times, a further statistically significant increase in this indicator was recorded after 60 minutes of reoxygenation; the ALT activity during this period was 3.8 times higher than the control indices. 3 hours after the restoration of blood flow in the ischemic liver, the activity of the analyzed marker reached its maximum values in blood plasma - 8.8 times higher than that of intact animals. After that, the ALT activity gradually decreased during the day, so 8 hours after the start of reperfusion, the activity exceeded the control figures by 5.2 times, and after a day - only by 1.6 times. One of the interesting features is that a wide scatter of indicators in animals at the stages of 1 and 2 hours of reperfusion should be highlighted, which can be regarded as an increase in ALT activity in animals, manifested to varying degrees depending on the individual characteristics of the animals, different initial states of the organism. At the same time, a statistically significant increase in the indicator was recorded only in the group of animals after a 3-hour period of blood flow restoration. This makes it possible to recommend the use of this period in experimental studies of ischemia-reperfusion syndrome, including its correction, more reasonably. To use a 1-2 hour reperfusion period for the same purposes, it is necessary to consider the possibility of either increasing the sample or preliminary assessment of the resistance of rats to hypoxia-reoxygenation. 
Popov K.A. et al RUDN Journal of Medicine. 2020;24(4):293-303

Table 1

Changes in hepatocyte cytolysis markers at different periods of reperfusion after 20 -minute ischemia of rat liver $(\mathrm{Me}(\mathrm{p} 0,25 / \mathrm{p} 0,75))$

\begin{tabular}{|c|c|c|c|}
\hline \multirow{2}{*}{$\begin{array}{c}\text { Studied groups/ } \\
\text { Reperfusion time }\end{array}$} & ALT, U/I & Studied indices & AST, U/I \\
\cline { 2 - 4 } & $23,5(18,4 / 25,5)$ & $44,6(42,9 / 51,9)$ & $152,3(99,2 / 167,5)$ \\
\hline Control & $49,8(45,1 / 60,0)^{\star}$ & $62,2(55,1 / 67,0)^{\star}$ & $224,5(203,8 / 313,5)^{\star}$ \\
\hline 5 min. & $78,6(51,8 / 93,7)^{\star}$ & $65,3(47,8 / 100,3)^{\star}$ & $325,0(227,0 / 521,5)^{\star}$ \\
\hline 15 min. & $47,4(44,5 / 78,2)^{\star}$ & $85,2(80,0 / 90,7)^{\star}$ & $498,0(479,0 / 544,0)^{\star}$ \\
\hline 30 min. & $89,6(82,1 / 138,5)^{\star \wedge}$ & $156,6(130,8 / 199,6)^{\star \wedge}$ & $1519,0(971,4 / 2585,0)^{\star \wedge}$ \\
\hline 60 min. & $84,4(77,4 / 143,8)^{\star}$ & $85,6(82,1 / 159,6)^{\star}$ & $1113,4(823,7 / 1545,9)^{\star}$ \\
\hline 120 min. & $207,9(149,1 / 241,5)^{\star \wedge}$ & $240,9(156,6 / 268,9)^{\star \wedge}$ & $1112,8(764,3 / 1320,3)^{\star}$ \\
\hline 180 min. & $121,8(93,8 / 170,1)^{\star}$ & $118,55(86,8 / 176,7)^{\star \wedge}$ & $459,5(308,2 / 783,8)^{\star \wedge}$ \\
\hline 8 h. & $38,3(33,9 / 48,2)^{\star \wedge}$ & $79,8(68,7 / 82,4)^{\star \wedge}$ & $390,7(330,8 / 450,7)^{\star}$ \\
\hline
\end{tabular}

Note:* - statistically significant differences $(p<0,05)$ from the same index of the control group; ${ }^{\wedge}$ - statistically significant differences $(p<0,05)$ from the index of the previous group.

The dynamics of AST activity during the development of reperfusion syndrome practically coincided with that for ALT (Table 1). A feature was the initially higher values of the enzyme activity in animals of the control group and in animals of the experimental groups accordingly against the background of a pathological process. AST activity, as well as ALT activity, increased by 1.4 times already after 5 minutes of reperfusion. 60 minutes after the restoration of blood flow in the vascular bundle of the hepatic hilus, the AST activity exceeded the control values by 3.5 times. This period (60-120 minutes of reperfusion) was also characterized by amplitude changes in the activity of the enzyme with a significant increase by the $3^{\text {rd }}$ hour of reoxygenation - up to values 5.4 times higher than the level of a similar parameter in intact rats. Determination of AST activity after 8 hours and a day showed a gradual decrease in the indicator, similar to the dynamics of changes in ALT activity. In general, the increase in ALT activity was characterized by high relative values in comparison with the group of intact animals.
The dynamics of changes in LDH activity in animals of the experimental groups was significantly different (Table 1). There was also a slight increase in the parameter already 5 minutes after the restoration of blood flow - by 1.5 times. Subsequently, the average values of the enzyme activity and the scatter of the index within the group gradually increased, but a statistically significant increase in the marker was recorded by the 60th minute of reperfusion, while the values of LDH activity increased by 7.3-10.0 times in animals after 2- and 3-hour reoxygenation. Later, as well as for aminotransferases, a decrease in the activity of the analyzed enzyme was recorded, which did not reach the control values. Thus, the main feature of the dynamics of LDH activity was the achievement of the maximum value already by 60 minutes of reperfusion and the absence of a peak in the indicator after 180 minutes of the experiment.

Changes in hepatocyte cytolysis markers at different periods of reperfusion after 20-minute ischemia of rat liver (Me(p0,25/p0,75))

\begin{tabular}{|c|c|c|}
\hline \multirow{2}{*}{$\begin{array}{c}\text { Studied groups/ } \\
\text { Reperfusion time }\end{array}$} & GST, U/I & Ltudied indices \\
\cline { 2 - 3 } & $0,023(0,020 / 0,026)$ & $2,8(2,6 / 3,0)$ \\
\hline Control & $0,108(0,094 / 0,120)^{\star}$ & $11,0(10,6 / 11,4)^{\star}$ \\
\hline 5 min. & $0,095(0,067 / 0,127)^{\star}$ & $8,0(7,0 / 8,3)^{\star \wedge}$ \\
\hline 15 min. & $0,087(0,085 / 0,101)^{\star}$ & $8,1(6,8 / 10,5)^{\star}$ \\
\hline 30 min. & $0,123(0,112 / 0,192)^{\star \wedge}$ & $3,0(6,8 / 9,2)^{\star}$ \\
\hline 120 min. & $0,052(0,050 / 0,056)^{\star \wedge}$ & $5,9(3,8 / 4,9)^{\star \wedge}$ \\
\hline 180 min. & $0,050(0,048 / 0,058)^{\star}$ & $5,1(4,3 / 6,1)^{\star}$ \\
\hline 8 h. & $0,030(0,025 / 0,037)^{\star}$ & $2,5(2,3 / 2,7)^{\wedge}$ \\
\hline 1 day & $0,027(0,025 / 0,031)$ & \\
\hline
\end{tabular}

Note:* - statistically significant differences $(p<0,05)$ from the same index of the control group; ${ }^{\wedge}-$ statistically significant differences $(p<0,05)$ from the index of the previous group. 
The activity of glutathione transferase changed in a different way (Table 2), in contrast to the activity of transaminases and LDH. The most significant increase in the activity of the analyzed enzyme was observed already at the $1^{\text {st }}$ stage of the experiment after 5 minutes of reperfusion. The activity of glutathione transferase in this period increased by 4.7 times. Subsequently, a slight increase in activity was determined after 60 minutes of restoration of blood flow - the value of the considered indicator exceeded the control figures by 5.3 times, which was especially distinguished against the background of a slight trend towards a decrease in enzymatic activity in animals after 15-30 minutes of reperfusion. Against the background of 2-hour reperfusion, the activity of glutathione transferase decreased to a level 2.3 times higher than the control values, and after 8 hours it did not differ from the value of the corresponding parameter in the group of intact rats.

The concentration of lactate is not a marker of hepatocyte cytolysis, but it was interesting to follow its changes against the background of its expected growth in the presence of hypoxia. In fact, the concentration of the analyzed metabolite was maximal immediately, i.e. 5 minutes after the end of the ischemic period. At this stage, the concentration of lactate exceeded the control values by 3.9 times. During further observation, the content of lactic acid in blood plasma progressively decreased. The most significant points of decrease in lactate concentration were 15 minutes and 120 minutes, in addition, the normal level of lactic acid was determined one day after the restoration of blood flow.

Thus, in our opinion, two main peaks of indicators can be distinguished: a 5-minute period after the restoration of blood flow - the maximum activity of glutathione transferase and the concentration of lactic acid; 60-180 minutes of reperfusion is the peak of aminotransferase activity, a significant increase in the activity of which began from 60 minutes after the restoration of blood flow and reached a maximum by the $3^{\text {rd }}$ hour of reperfusion and LDH, the peak of which was recorded already by the 60th minute of revascularization. An increase in the first two indicators by the $5^{\text {th }}$ minute of the experiment is associated with changes in the ischemic period, an increase in the activity of AST, ALT and $\mathrm{LDH}$ to a greater extent reflects an increase in liver damage during the reperfusion period, the time limits of the main damaging effect of which are also indicated by an increase in glutathione transferase activity and a delay in the decrease in concentration lactate.

\section{Conclusion}

Depending on the goals and objectives, a reasonable choice of one or another marker of liver damage in an acute experiment is required. Assessment of organ damage in the ischemic period and the anti-ischemic effect of metabolic drugs can be carried out by determining the increase in lactate concentration and glutathione transferase activity almost immediately after the restoration of blood flow. It is more expedient to evaluate the development of injuries during the reperfusion period using the classic markers of hepatocyte cytolysis - AST, ALT, and LDH. More homogeneous and easily comparable results can be obtained when determining these indicators after a 3-hour period of blood flow restoration, at the same time the maximum values of markers are recorded under the condition of 20-minute total liver ischemia. 
Во врачебной практике оценка повреждения и функционального состояния печени является одной из ведущих задач клинико-лабораторной диагностики. Для этого традиционно используют определение в крови активности ряда индикаторных ферментов, обладающих относительной органоспецифичностью, таких как аспартатаминотрансфераза (АСТ), аланинаминотрансфераза (АЛТ), лактатдегидрогеназа (ЛДГ), сорбитолдегидрогеназа, щелочная фосфатаза и ү-глутамилтрансфераза [1]. Изменение активности аминотрансфераз чаще свидетельствует о цитолизе клеток печения, активность щелочной фосфатазы возрастает при холестазе [2, 3]. Учитывая белоксинтезирующую функцию печени, в ряде случаев информативным может быть определение содержания сывороточного альбумина в плазме крови, особенно при хронических заболеваниях, и протромбинового времени, отражающего активность факторов свертывания крови, также синтезируемых в печени. Учитывая детоксикационную функцию, информативным может быть определение билирубина и его метаболитов. Главным недостатком всех перечисленных маркеров является низкая их специфичность по отношению к заболеваниям печени [4]. Между тем при условии верификации повреждения печени другими методами оценка вышеперечисленных показателей оправдана для целей лабораторного мониторинга [5, 6]. Существуют динамические методы оценки функционального состояния печени, основанные на определении скорости метаболизирования в печени различных субстратов, таких как бромсульфталеин, индоцианин зеленый, лидокаин и др. [7-9]. Данные методы применяются достаточно редко в клинической практике, поскольку инвазивны, требуют сложного оборудования и длительного времени исследования. Принципы и подходы к оценке экспериментального повреждения печени у крыс и других лабораторных животных аналогичные, однако, имеются особенности, связанные с выраженностью и диагностической значимостью тех или иных маркеров, динамикой изменений в процессе повреждения [10, 11].

Целью настоящего исследования было определение динамики изменений маркеров повреждения печени у крыс на разных сроках реперфузии после 20-минутной ишемии для выбора показателей, наиболее информативно характеризующих состояние животных в условиях проведения коррекции ишемически-реперфузионного синдрома.

\section{Материалы и методы}

Исследование проведено на 120 лабораторных животных - белые нелинейные крысы-самцы (массой 200-250 грамм). Животные были разделены на 8 групп по 15 особей, всем животным выполнялось моделирование ишемии печени путем пережатия аналога печеночно-двенадцатиперстной связки сосудистым зажимом на 20 минут. Затем у разных групп крыс производили забор крови в разные сроки реперфузии - 5, 15, 30, 60, 120, 180 минут, 8 часов и сутки. Выполнение экспериментальных работ с лабораторными животными проводили на фоне общей анестезии с использованием Золетила 100 («Virbac», France) в дозировке 10 мг/кг внутримышечно. Исследование было одобрено независимым этическим комитетом при ФГБОУ ВО КубГМУ Минздрава России (протокол № 51 от 23.05.2017 г.) и осуществлялось в соответствии с принципами, изложенными в «Европейской конвенции по защите позвоночных животных» (Страсбург, 1986). Сравнение данных, полученных в эксперименте у крыс опытных групп, также проводили с результатами оценки аналогичных показателей у группы интактных животных (контрольная группа, n=20), содержавшихся в аналогичных условиях [2].

В плазме крови лабораторных животных активность аланинаминотрансферазы (АЛТ), аспартатаминотрансферазы (АСТ), лактатдегидрогеназы (ЛДГ) и концентрацию лактата определяли кинетическими методами с использованием наборов реагентов «Витал Девелопмент Корпорэйшн» (Санкт-Петербург, Россия). Активность глутатионтрансферазы (ГST) определяли по способу, предполагающему регистрацию изменений оптической плотности при 340 нм в результате конденсации глутатиона с динитрохлорбензолом [12].

Для статистической обработки полученных данных использовали программное обеспечение AnalystSoft Inc., StatPlus - программа статистического анализа. Версия 7. (www.analystsoft.com/ru/). 
С учетом небольшого размера выборок и отличного от нормального характера распределения (оценивали по критерию Шапиро-Вилка) для определения значимости различий между показателями групп животных с разным временем реперфузии, а также контрольной группы использовали непараметрический критерий Краскела-Уоллиса (для нескольких независимых групп) с последующим (при необходимости) попарным сравнением с помощью критерия Манна-Уитни. Результаты в статье представлены в виде медианы, планки погрешностей отражают разброс между 25-м и 75-м процентилями. Различия между показателями групп считали статистически значимыми при уровне $\mathrm{p}<0,05$.

\section{Результаты и обсуждение}

Анализ изменений классических маркеров в динамике развития ишемически-реперфузионного повреждения у крыс показал разные результаты для активности АЛТ, АCT, ЛДГ, ГST и концентрации лактата. Активность всех маркеров возрастала уже на 5-й минуте реперфузии, но в дальнейшем динамика показателей была различной. Активность АЛТ (таблица 1) увеличивалась к 5-й минуте реперфузионного периода в 2,1 раза, дальнейший статистически значимый рост рассматриваемого показателя был зафиксирован после 60 -минутной реоксигенации, активность АЛТ в этот период была в 3,8 раза выше контрольных цифр. Спустя 3 часа после восстановления кровотока в ишемизированной печени активность анализируемого маркера достигала своих максимальных значений в плазме крови в 8,8 раза выше показателя интактных животных. После этого активность АЛТ постепенно в течение суток снижалась, так, через 8 часов после начала реперфузии активность превышала контрольные цифры в 5,2 раза, а через сутки - только в 1,6 раза. Из интересных особенностей следует выделить широкий разброс показателей у животных на этапах 1-2-часовой реперфузии, что можно расценивать как рост активности АЛТ у животных, проявляющийся в разной степени в зависимости от индивидуальных особенностей животных, разного исходного состояния организма. При этом статистически значимое увеличение показателя было зафиксировано только в группе животных после 3-часового периода восстановления кровотока. Это позволяет более обосновано рекомендовать использовать данный период в экспериментальных исследованиях ишемиически-реперфузионного синдрома, в том числе его коррекции. Для использования 1-2-часового периода реперфузии с теми же целями необходимо рассмотреть возможность или увеличения выборки, или предварительной оценки резистентности крыс к гипоксии-реоксигенации.

Таблица 1

Изменение маркеров цитолиза гепатоцитов в разные сроки реперфузии после 20-минутной ишемии печени крыс $(\mathrm{Me}(\mathrm{p} 0,25 / \mathrm{p} 0,75))$

\begin{tabular}{|c|c|c|c|}
\hline \multirow{2}{*}{$\begin{array}{c}\text { Исследуемые группы } \\
\text { время реперфузии }\end{array}$} & АЛТ, ед/л & АСТ, ед/л & \multicolumn{2}{|c|}{ Исследуемые показатели } \\
\cline { 2 - 4 } & $23,5(18,4 / 25,5)$ & $44,6(42,9 / 51,9)$ & $152,3(99,2 / 167,5)$ \\
\hline Контроль & $49,8(45,1 / 60,0)^{\star}$ & $62,2(55,1 / 67,0)^{\star}$ & $224,5(203,8 / 313,5)^{\star}$ \\
\hline 5 мин & $78,6(51,8 / 93,7)^{\star}$ & $65,3(47,8 / 100,3)^{\star}$ & $325,0(227,0 / 521,5)^{\star}$ \\
\hline 15 мин & $47,4(44,5 / 78,2)^{\star}$ & $85,2(80,0 / 90,7)^{\star}$ & $498,0(479,0 / 544,0)^{\star}$ \\
\hline 30 мин & $89,6(82,1 / 138,5)^{\star \wedge}$ & $156,6(130,8 / 199,6)^{\star \wedge}$ & $1519,0(971,4 / 2585,0)^{\star \wedge}$ \\
\hline 60 мин & $84,4(77,4 / 143,8)^{\star}$ & $85,6(82,1 / 159,6)^{\star}$ & $1113,4(823,7 / 1545,9)^{\star}$ \\
\hline 120 мин & $207,9(149,1 / 241,5)^{\star \wedge}$ & $240,9(156,6 / 268,9)^{\star \wedge}$ & $1112,8(764,3 / 1320,3)^{\star}$ \\
\hline 18 мин & $121,8(93,8 / 170,1)^{\star}$ & $118,55(86,8 / 176,7)^{\star \wedge}$ & $459,5(308,2 / 783,8)^{\star \wedge}$ \\
\hline $8 ч$ & $38,3(33,9 / 48,2)^{\star \wedge}$ & $79,8(68,7 / 82,4)^{\star \wedge}$ & $390,7(330,8 / 450,7)^{\star}$ \\
\hline сутки &
\end{tabular}

Примечание: * - статистически значимые отличия $(p<0,05)$ от соответствующего показателя контрольной группы; ^ статистически значимые отличия ( $p<0,05)$ от показателя предыдущей группы. 
Динамика активности АСТ в процессе развития реперфузионного синдрома практически совпадала с таковой для АЛТ (таблица 1). Особенностью были исходно более высокие значения активности фермента у животных контрольной группы и соответственно у животных опытных групп на фоне патологического процесса. Активность АСТ, также как и АЛТ, увеличивалась в 1,4 раза уже спустя 5 минут реперфузии. Спустя 60 минут после восстановления кровотока в сосудистом пучке ворот печени активность АСТ превышала контрольные значения в 3,5 раза. Для этого периода (60-120 минут реперфузии) также были характерны амплитудные изменения активности фермента со значительным ростом его к 3-м часам реоксигенации - до значений в 5,4 раза превышающим уровень аналогичного параметра интактных крыс. Определение активности АСТ через 8 часов и сутки показала постепенное снижение показателя, аналогичное динамике изменений активности АЛТ. В целом же увеличение активности АЛТ характеризовалось большими от- носительными значениями в сравнении с группой интактных животных.

Динамика изменений активности ЛДГ у животных опытных групп существенно отличалась (таблица 1). Также отмечался небольшой рост параметра уже через 5 минут после восстановления кровотокав 1,5 раза. В дальнейшем постепенно увеличивались средние значения активности фермента и разброс показателя внутри группы, но статистически значимый рост маркера был зафиксирован к 60-й минуте реперфузии с сохранением увеличенных в 7,3-10,0 раза значений активности ЛДГ у животных после 2-х и 3-х часовой реоксигенации. В дальнейшем также как и для аминотрансфераз регистрировалось снижение активности анализируемого фермента, не достигающее контрольных значений. Таким образом, основной особенностью динамики активности ЛДГ было достижение максимального значения уже к 60-ти минутам реперфузии и отсутствие пика показателя через 180 минут эксперимента.

Изменение маркеров цитолиза гепатоцитов в разные сроки реперфузии после 20-ти минутной ишемии печени крыс $(\mathrm{Me}(\mathrm{p} 0,25 / \mathrm{p} 0,75))$

\begin{tabular}{|c|c|c|}
\hline \multirow{2}{*}{$\begin{array}{c}\text { Исследуемые группы / время } \\
\text { реперфузии }\end{array}$} & ГSТ, ед/л & Исследуемые показатели \\
\cline { 2 - 3 } & $0,023(0,020 / 0,026)$ & $2,8(2,6 / 3,0)$ \\
\hline Контроль & $0,108(0,094 / 0,120)^{\star}$ & $8,0(10,6 / 11,4)^{\star}$ \\
\hline 5 мин & $0,095(0,067 / 0,127)^{\star}$ & $8,1(6,8 / 10,5)^{\star}$ \\
\hline 15 мин & $0,087(0,085 / 0,101)^{\star}$ & $7,0(6,8 / 9,2)^{\star}$ \\
\hline 30 мин & $0,123(0,112 / 0,192)^{\star \wedge}$ & $3,9(3,8 / 4,9)^{\star \wedge}$ \\
\hline 60 мин & $0,052(0,050 / 0,056)^{\star \wedge}$ & $5,9(4,3 / 6,1)^{\star}$ \\
\hline 120 мин & $0,050(0,048 / 0,058)^{\star}$ & $5,1(4,3 / 6,7)^{\star}$ \\
\hline 180 мин & $0,030(0,025 / 0,037)^{\wedge}$ & $2,5(2,3 / 2,7)^{\wedge}$ \\
\hline Сутки & $0,027(0,025 / 0,031)$ & \\
\hline
\end{tabular}

Примечание: * - статистически значимые отличия $(p<0,05)$ от соответствующего показателя контрольной группы; ^ - статистически значимые отличия $(p<0,05)$ от показателя предыдущей группы.

Активность глутатионтрансферазы изменялась другим образом (таблица 2), в отличие от активности трансаминаз и ЛДГ. Наиболее значительное увеличение активности анализируемого фермента наблюдалось уже на 1-м этапе эксперимента - после 5-минутной реперфузии. Активность глутатионтрансферазы в этом периоде была увеличена в 4,7 раза. В дальнейшем было определено еще небольшое увеличение активности через 60 минут восстановления кровотока - значение рассматриваемого показателя превышала контрольные цифры в 5,3 раза, что особенно выделялось на фоне небольшой тенденции к снижению ферментативной активности у животных после 15-30-минутной ре- 
перфузии. На фоне 2-часовой реперфузии активность глутатионтрансферазы снижалась до уровня, в 2,3 раза превышающего контрольные значения, а спустя 8 часов уже не отличалась от значения соответствующего параметра группы интактных крыс.

Концентрация лактата конечно не является маркером цитолиза гепатоцитов, однако проследить за ее изменениями было интересно, учитывая ожидаемый ее рост на фоне гипоксии. На самом деле концентрация анализируемого метаболита была максимальна сразу - спустя 5 минут после окончания ишемического периода. На этом этапе концентрация лактата превышала контрольные значения в 3,9 раза. В ходе дальнейшего наблюдения содержание молочной кислоты в плазме крови прогрессирующе снижалось. Наиболее значительными точками уменьшения концентрации лактата были 15 минут и 120 минут, кроме того нормальный уровень молочной кислоты был определен через сутки после восстановления кровотока.

Таким образом, на наш взгляд можно выделить два основных пика показателей: 5-минутный период после восстановления кровотока - максимум активности глутатионтрансферазы и концентрации молочной кислоты; 60-180 минут реперфузии - пик активности аминотрансфераз, значительный рост активности которых начинался с 60-ти минут после восстановления кровотока и достигал максимума к 3-му часу реперфузии и ЛДГ, пик активности которой регистрировался уже к 60-й минуте реваскуляризации. Увеличение первых двух показателей к 5-й минуте эксперимента связано с изменениями в ишемический период, увеличение активности АСТ, АЛТ и ЛДГ в большей степени отражает нарастание повреждений печени в реперфузионный период, временные границы основного повреждающего действия которого также обозначены ростом активности глутатионтрансферазы и задержкой снижения концентрации лактата.

\section{Выводы}

В зависимости от целей и задач требуется обоснованный выбор того или иного маркера повреждения печени в остром эксперименте. Оценка повреждения органа в ишемическом периоде и противоишемического действия метаболических препаратов может проводиться с определением нарастания концентрации лактата и активности глутатионтрансферазы практически сразу после восстановления кровотока. Развитие повреждений в реперфузионный период более целесообразно оценивать с использованием классических маркеров цитолиза гепатоцитов - АСТ, АЛТ и ЛДГ. Более однородные и легко сравнимые результаты можно получить при определении данных показателей после 3-часового периода восстановления кровотока, в это же время регистрируются максимальные значения маркеров при условии 20-минутной тотальной ишемии печени.

\section{References}

1. Voloshchuk O., Kopylchuk G. Serum sorbitol dehydrogenase activity as a sensitive marker of liver damage. Laboratory diagnostics. Eastern Europe. 2015;2(14):94-99. (In Russ).

2. Tsymbalyuk I.Y., Manuilov A.M., Popov K.A., Basov A.A. Metabolic correction of the ischemia-reperfusive injury with sodium dichloroacetate in vascular isolation of the liver in experiment. Novosti Khirurgii. 2017;25(5):447-453. doi: 10.18484/23050047.2017.5.447. (In Russ.)

3. Saidi R.F., Kenari S.K. Liver ischemia/reperfusion injury: an overview. J. Invest. Surg. 2014;27(6):366-379. doi:10.3109/089 41939.2014.932473.

4. Liang J., Zhou Y., Wang Z., Chen H. Relationship between liver damage and serum levels of IL-18, TNF-alpha and NO in patients with acute pancreatitis. Nan Fang Yi Ke Da Хие Хие Bao. 2010;30(8):1912-1914.

5. Basov A.A., Elkina A.A., Samkov A.A., Volchenko N.N., Baryshev M.G., Dzhimak S.S., et al. Influence of deuteriumdepleted water on the isotope $\mathrm{D} / \mathrm{H}$ composition of liver tissue and morphological development of rats at different periods of ontogenesis. Iranian Biomedical Journal. 2019;23(2):129-141.

6. Johansen M.J., Gade J., Stender S., Frithioff-Bøjsøe C., Lund M AV., Chabanova E., et al. The effect of overweight and obesity on liver biochemical markers in children and adolescents. J. Clin. Endocrinol. Metab. 2020;105(2): dgz010. doi:10.1210/clinem/ dgz010.

7. Dzidzava I.I., Slobodyanik A.V., Kudryavtseva A.V., Zheleznyak I.S., Kotiv B.N., Alentyev S.A., et al. The results of CT-volumetry and clearance test with indocyanine green as indications for preoperative portal vein embolization. Annals of HPB surgery. 2016;21(3):34-46. (In Russ).

8. Halle B.M., Poulsen T.D., Pedersen H.P. Indocyanine green plasma disappearance rate as dynamic liver function test in critically ill patients. Acta Anaesthesiol Scand. 2014;58(10):1214-1219. doi:10.1111/aas.12406.

9. Sakka S.G. Assessment of liver perfusion and function by indocyanine green in the perioperative setting and in critically ill 
patients. J. Clin. Monit. Comput. 2018;32(5):787-796. doi:10.1007/ s10877-017-0073-4.

10. Dzhimak S.S., Basov A.A., Volchenko N.N., Samkov A.A., Baryshev M.G., Fedulova L.V. Changes in the functional activity of mitochondria isolated from the liver of rat that passed the preadaptation to ultra-low deuterium concentration. Doklady Biochemistry and Biophysics. 2017;476(1):323-325.

11. Ge Y., Zhang Q., Jiao Z., Li H., Bai G., Wang H. Adipose-derived stem cells reduce liver oxidative stress and autophagy induced by ischemia-reperfusion and hepatectomy injury in swine. Life Sci. 2018;214:62-69. doi:10.1016/j.lfs.2018.10.054.

12. Karpishchenko A.I. Handbook. Medical Laboratory Technology. Sankt-Petersburg: Intermedika, 2002. (In Russ).

\section{Библиографический список}

1. Волощук О.Н., Копыльчук Г.П. Активность сорбитолдегидрогеназы сыворотки как чувствительный маркер повреждения печени // Лабораторная диагностика. Восточная Европа. 2015. № 2 (14). С. 94-99.

2. Ц Цымбалюк И.Ю., Мануйлов А.М., Попов К.А., Басов А.А. Метаболическая коррекция дихлорацетатом натрия ишемически-реперфузионного повреждения при сосудистой изоляции печени в эксперименте // Новости хирургии. 2017. 25 (5). C. 447-453. doi: 10.18484/2305-0047.2017.5.447.

3. Saidi R.F., Kenari S.K. Liver ischemia/reperfusion injury: an overview // J. Invest. Surg. 2014. V. 27 (6). P. 366-379. doi:10.3109/08941939.2014.932473.

4. Liang J., Zhou Y., Wang Z., Chen H. Relationship between liver damage and serum levels of IL-18, TNF-alpha and NO in patients with acute pancreatitis // Nan Fang Yi Ke Da Xue Xue Bao. 2010. V. 30 (8). P. 1912-1914.

5. Basov A.A., Elkina A.A., Samkov A.A., Volchenko N.N., Baryshev M.G., Dzhimak S.S., et al. Influence of deuteriumdepleted water on the isotope $\mathrm{D} / \mathrm{H}$ composition of liver tissue and morphological development of rats at different periods of ontogenesis // Iranian Biomedical Journal. 2019. V. 23. № 2. P. 129-141.

6. Johansen M.J., Gade J., Stender S., Frithioff-Bøjsøe C., Lund M. $A V$., Chabanova E., et al. The effect of overweight and obesity on liver biochemical markers in children and adolescents // J. Clin. Endocrinol. Metab. 2020. V. 105 (2). dgz010. doi:10.1210/ clinem/dgz010.

7. Дзидзава И.И., Слободяник А.В., Кудрявцева А.В., Железняк И.С., Котив Б.Н., Алентьев С.А., и др. Применение КТ-волюметрии и клиренс-теста с индоцианином зеленым для определения показаний к предоперационной эмболизации воротной вены // Анналы хирургической гепатологии. 2016. Т. 21 (3). С. 34-46.

8. Halle B.M., Poulsen T.D., Pedersen H.P. Indocyanine green plasma disappearance rate as dynamic liver function test in critically ill patients // Acta Anaesthesiol. Scand. 2014. V. 58 (10). P. 1214-1219. doi:10.1111/aas.12406.

9. Sakka S.G. Assessment of liver perfusion and function by indocyanine green in the perioperative setting and in critically ill patients // J. Clin. Monit. Comput. 2018. V. 32 (5). P. 787-796. doi: 10.1007/s10877-017-0073-4.

10. Dzhimak S.S., Basov A.A., Volchenko N.N., Samkov A.A., Baryshev M.G., Fedulova L.V. Changes in the functional activity of mitochondria isolated from the liver of rat that passed the preadaptation to ultra-low deuterium concentration // Doklady Biochemistry and Biophysics. 2017. V. 476. № 1. P. 323-325.

11. Ge Y., Zhang Q., Jiao Z., Li H., Bai G., Wang H. Adipose-derived stem cells reduce liver oxidative stress and autophagy induced by ischemia-reperfusion and hepatectomy injury in swine // Life Sci. 2018. V. 214. P. 62-69. doi:10.1016/j.lfs.2018.10.054.

12. Карпищенко А.И. Медицинские лабораторные технологии. Справочник. СПб: Интермедика, 2002. 600 с.

Corresponding author: Popov Konstantin Andreevich - PhD, Associate Professor of the department of fundamental and clinical biochemistry Kuban State Medical University, 350063, Russia, Krasnodar, Sedina str., 4. E-mail: naftalin444@mail.ru Popov K.A. ORCID: 0000-0002-3649-1361, SPIN: 9456-9710

Tsymbalyuk I. Yu. ORCID0000-0002-5711-6659, SPIN-код: 4493-0738

Sepiashvili R.I. ORCID: 0000-0001-8112-2082, SPIN-код: 6921-7356

Bykov I.M. ORCID0000-0001-7325-536, SPIN-код: 9977-6613

Ustinova E.S. ORCID0000-0003-1916-2897

Bykov M.I. ORCID: 0000-0001-6806-1414, SPIN-код: 2909-3520

Ответственный за переписку: Попов Константин Андреевич - к.м.н., ассистент кафедры фундаментальной и клинической биохимии Кубанского государственного медицинского университета, 350063, Россия, г. Краснодар, улица Седина, дом 4. E-mail: naftalin444@mail.ru

Попов K.A. SPIN: 9456-9710; ORCID: 0000-0002-3649-1361

Цымбалюк И.Ю. SPIN-код: 4493-0738; ORCID0000-0002-5711-6659

Сепиашвили Р.И. SPIN-код: 6921-7356; ORCID: 0000-0001-8112-2082

Быков И.М. SPIN-код: 9977-6613; ORCID0000-0001-7325-536

Устинова E.C. ORCID0000-0003-1916-2897

Быков М.И. SPIN-код: 2909-3520; ORCID: 0000-0001-6806-1414 